\title{
Innovation in Citizen Science - Perspectives on Science-Policy Advances
}

\author{
Susanne Hecker ${ }^{*}, \dagger$, Rick Bonney ${ }^{\ddagger}$, Muki Haklay§, Franz Hölkerll, Heribert Hofer», \\ Claudia Goebel $^{* *}$, Margaret Gold ${ }^{\dagger \dagger}$, Zen Makuch*, Marisa Ponti§§, Anett Richter ${ }^{*}$, , Lucy

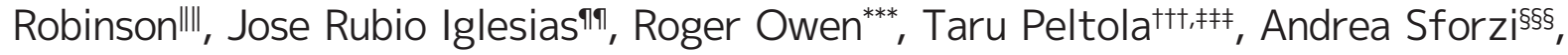

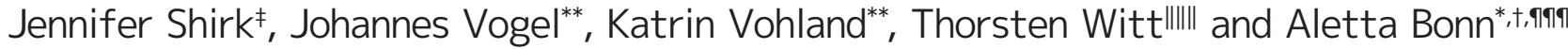

Citizen science is growing as a field of research with contributions from diverse disciplines, promoting innovation in science, society, and policy. Inter- and transdisciplinary discussions and critical analyses are needed to use the current momentum to evaluate, demonstrate, and build on the advances that have been made in the past few years. This paper synthesizes results of discussions at the first international citizen science conference of the European Citizen Science Association (ECSA) in 2016 in Berlin, Germany, and distills major points of the discourse into key recommendations. To enhance innovation in science, citizen science needs to clearly demonstrate its scientific benefit, branch out across disciplines, and foster active networking and new formats of collaboration, including true co-design with participants. For fostering policy advances, it is important to embrace opportunities for policy-relevant monitoring and policy development and to work with science funders to find adequate avenues and evaluation tools to support citizen science. From a society angle it is crucial to engage with societal actors in various formats that suit participants and to evaluate two-way learning outcomes as well as to develop the transformative role of science communication. We hope that these key perspectives will promote citizen science progress at the science-society-policy interface.

Keywords: innovation; science impact; science-policy interface; citizen science communication; Europe

\section{Introduction}

The long tradition of volunteer engagement in science has taken a big leap forward over the past two decades. Varied approaches of public engagement in science, public understanding of science, crowdsourcing, and community science have come together under the umbrella of citizen science. The result is a growing, global, citizen science community devoted to working together to bridge the science-society-policy interface. Citizen science is increasingly recognized as a distinct field of research (Jordan et al. 2015, Haklay 2016) informed by many scientific disciplines and supported by numerous citizen science projects and publications (Kullenberg and Kasperowski 2016).

Citizen science projects now number in the thousands worldwide. In addition, citizen science platforms and capacity-building programmes foster the visibility of projects and establish networks for knowledge exchange within and among members of the citizen science community. Examples include Germany (Bürger schaffen

\footnotetext{
Imperial College London, UK

University of Gothenburg, SE

III Angela Marmont Centre, Natural History Museum, London, UK

Iq European Environment Agency, Copenhagen, DK

*** Scottish Environment Protection Agency, GB

tt† Finnish Environment Institute, Joensuu, FI

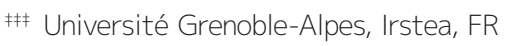

§§૬ Museo di Storia Naturale della Maremma, Grosseto, IT

\|IIII Wissenschaft im Dialog, Berlin, DE

ศศๆ Friedrich Schiller University Jena, Institute of Biodiversity, Jena, DE

Corresponding author: Susanne Hecker (susanne.hecker@idiv.de)
} 
Wissen), Austria (Österreich forscht), Switzerland (Schweiz forscht), Scotland (Scottish Citizen Science Portal), the US (e.g., SciStarter, Zooniverse, CitSci.org), and Australia (Atlas of Living Australia). These platforms promote networking of important citizen science actors and prospective stakeholders. They also foster learning and new developments (Richter et al. in press). Additionally, a range of policy documents such as green and white papers and practical resources, e.g., training materials, video clips, and guides, have been produced to facilitate the growth of citizen science in science, policy, and society (e.g., Bonn et al. 2016, Phillips et al. 2014, Pocock et al. 2014, Pettibone et al. 2016, Serrano Sanz et al. 2014).

The concept of citizen science has been further professionalized through the development of practitioner organisations in Europe (European Citizen Science Association-ECSA), the US (Citizen Science AssociationCSA), and Australia (Australian Citizen Science Association-ACSA) as well as several national networks (Göbel et al. 2016, Storksdieck et al. 2016). These groups allow researchers, citizens, and supporters of citizen science to work together on standards for the field and to develop methods for collaboratively evaluating the efficacy of the work (Jordan et al. 2015), both through analogue and digital communication (Tancoigne 2017).

Also in the past few years, numerous special issues of disciplinary journals have focused on citizen science, including Frontiers in Ecology and the Environment (Henderson 2012), Journal of Science Communication (Weitkamp 2016), Conservation Biology (Lukyanenko et al. 2016), Biological Conservation (Ellwood et al. 2017), Environmental Scientist (Ashcroft 2016), Citizen Science and Earth ObservationRemote Sensing 2016/17 (Fritz and Fonte 2016), Science \& Technology Studies (Kasperowski and Kullenberg in press), Remote Sensing in Ecology and Conservation (Pettorelli 2017), and Human Computation (Ramanauskaite and Haklay 2017). And 2016 saw the launch of the first scientific journal dedicated specifically to citizen science, which you are currently reading.

Several governments and policy organisations also are starting to support citizen science. In the US, the federal government established a website to provide a database on citizen science projects, to share a toolkit for setting up citizen science projects, and to aid in networking with members of federal agencies (CitizenScience.gov). The European Commission has supported and promoted citizen science through several calls in its research and innovation programme Horizon 2020. Currently, the EU Commission is developing and supporting targeted citizen science activities and capacity building programmes such as Citizens' Observatories, Collective Awareness Platforms (CAPS), and the Science with and for Society programme. The European Environment Agency is also actively engaging with national environment protection agencies, such as the Scottish Environment Protection Agency and the Finnish Environment Institute, to advance citizen science concepts for environmental monitoring (see also Owen and Parker in press).
To provide a forum for in-depth knowledge exchange and development of new citizen science collaborations and professional networks, we organised the First International ECSA conference in Berlin, Germany, 19-21 May 2016. With more than 360 participants from over 240 organisations and 30 countries, the conference spawned rich and fruitful discussions along the axes of science, policy, and society. Sessions included plenums with keynotes and discussion panels, parallel interactive workshops, and a marketplace with nearly one hundred posters and exhibitions. A range of open formats such as a ThinkCamp facilitated collaborative development of new projects, and the Berlin Citizen Science Fest, held in various locations across the city, involved Berlin grassroots science communities and the public (Gold and Ochu in press; Figure 1).

This paper presents and discusses the main outcomes and recommendations of the conference. We address three main fields: (a) How to promote stronger collaborations in science, (b) How to foster the impact of citizen science in the policy arena, and (c) How to engage more effectively with society. Further insights into the threeday conference can be gained via a "Storify" of the social media coverage (Gold 2016) as well as Muki Haklay's blog "Po Ve Sham" (Haklay 2016).

\section{Innovation and Inspiration for Science}

"Scientific endeavour that generates new knowledge or understanding" is the first of the ten principles of citizen science (Robinson et al. in press; see box). The value that citizen science brings to science, however, is a topic of hot discussion both within and outside the citizen science community (Dickinson et al. 2010, Dickinson et al. 2012, Riesch and Potter 2014, Tulloch et al. 2013, Vann-Sander et al. 2016). Key issues are when, how, and to what degree citizens can be involved in the research process. Most authors agree that citizen science can contribute substantially to data collection (e.g., Kullenberg and Kasperowski 2016, Hochachka et al. 2012), but concerns are sometimes voiced regarding data quality (Kosmala et al. 2016, Vantieghem et al. 2016, Kamp et al. 2016, Fowler et al. 2013). Several authors also point to the usefulness of citizen science for increasing understanding about scientific processes (Trumbull et al. 2000, Brossard et al. 2005, Shirk et al. 2012, Jordan et al. 2011) and for building public trust and acceptance for nature conservation (McKinley et al. 2017). In addition, citizen science is often claimed to contribute to public understanding of science and scientific literacy (Cronje et al. 2011, Bonney et al. 2009, Bonney et al. 2016, Brossard et al. 2005), a concept that is currently being evaluated (e.g., Merenlender et al. 2016; Phillips 2017).

At present, contributions of citizen science to the overall field of science arise in three main areas, which are captured in the perspectives and recommendations of the conference (Figure 2): Demonstrating scientific benefits of citizen science; branching out across disciplines, embracing new tools and technologies; and fostering active networking and new formats of collaboration. 


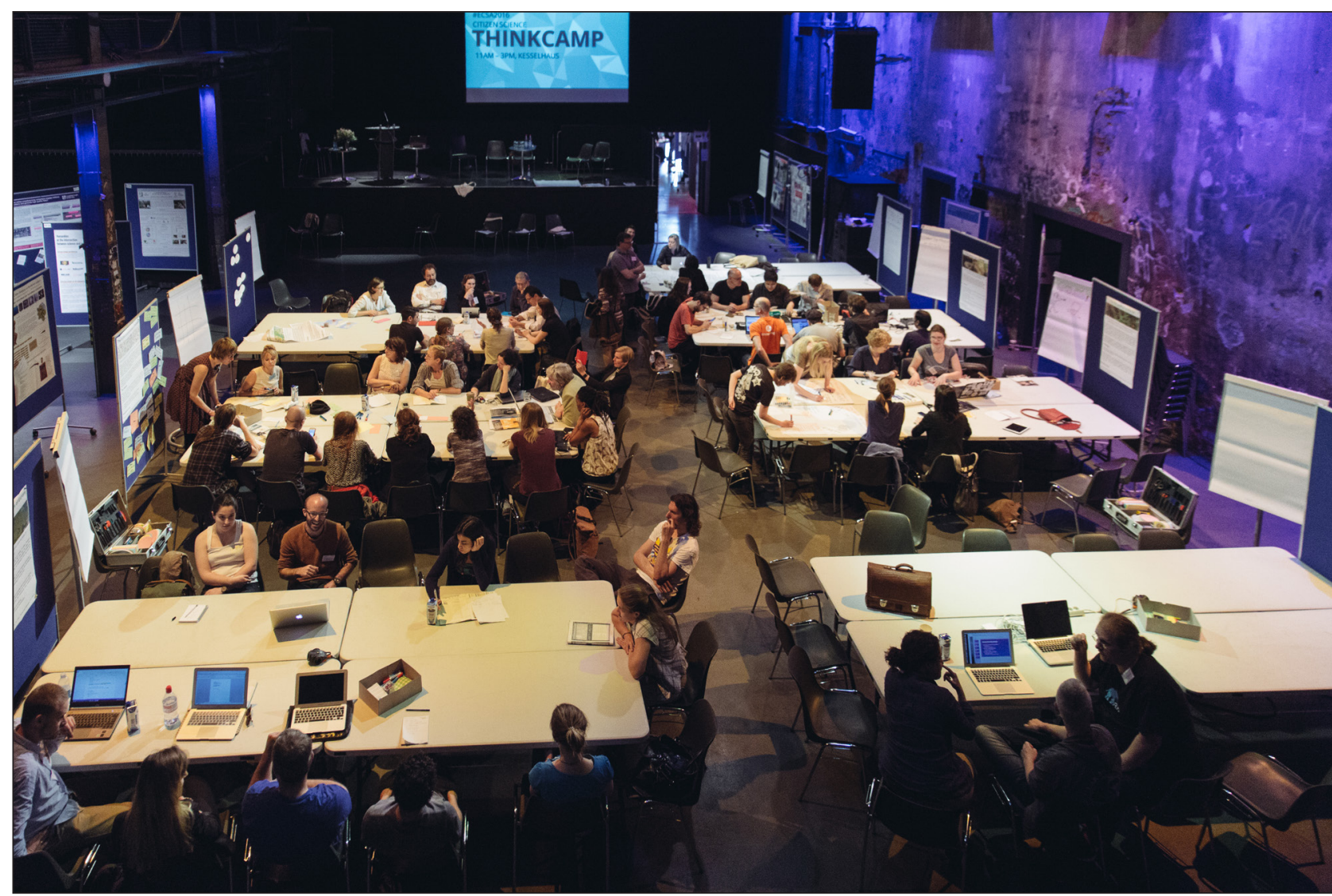

Figure 1: Participants of the first ECSA conference working together with Berlin grassroots science initiatives in the ThinkCamp (Photo: UFZ/F. Pappert).

\section{The ten principles of citizen science}

The ECSA ten principles of citizen science (Robinson et al. in press) provide guidance on best practices for citizen science projects with regard to aims, processes, and outcomes to enhance the credibility of citizen science. These principles provide a flexible concept that can be applied in diverse disciplines and situations as a somewhat normative framework of good practice. They apply to projects regardless of their level of citizen engagement from contributory to collegial (Shirk et al. 2012), and consider not only scientific outcomes but also the fair and respectful nature of collaboration among professional scientists and other actors. By March 2017, the ten principles had been translated into 26 languages by volunteer members of ECSA. These principles should now be tested, critically reflected upon and further developed in this fast-moving field.

\section{Demonstrate scientific benefits of citizen science: Creating new knowledge}

While some of the largest citizen science projects have been operating for several decades and a few for more than a century, over the past decade the number of projects has grown dramatically (Bonney et al. 2014). With careful attention to scientific design, data quality, and par- ticipant engagement, citizen science can promote significant scientific discovery and findings (Shirk and Bonney in press). Consider eBird, an online checklist program for reporting and accessing information about birds that was started by the Cornell Lab of Ornithology in 2002 and has already produced more than 100 peer-reviewed papers (Sullivan et al. 2014). A major factor contributing to the scientific impact of eBird is the rich nature of the project's data across large temporal and spatial scales using a monitoring design that allows for rigorous data analysis. In addition, because eBird data are open access, they are now being downloaded and utilized by many different groups and thereby amplify the scientific impact of the project (Sullivan et al. 2017).

The scientific impact of citizen science can be maximized when practitioners incorporate the growing number of best practices from the field. The process begins with carefully designing citizen science programmes to adhere to scientific standards in research design and data collection such that analyses can be published in scientific journals (McKinley et al. 2017, Ellwood et al. 2017). Also important is ensuring diversity and inclusion among citizen science participants to encourage broad participation that may foster in-depth scientific learning-by-doing (Bela et al. 2016). Practitioners also must understand the range of scientific outcomes that can be communicated to different audiences (Riesch et al. 2013), and they should increase and improve collaborations among citizen scientists and 
professional scientists, across disciplines, to enhance the reach, innovation, and impact of citizen science projects (Bonney et al. 2014).

In addition, the benefits and impacts of public participation in science will be better measured and understood when projects label themselves under the umbrella term of citizen science. While important debate has occurred over use of the term and its relationship to traditions such as volunteered science, crowd-sourced science, and participatory science (Haklay 2015), momentum is growing around use of the term as a focal point to better understand and quantify the impacts of all initiatives where public participants engage in scientific research (Eitzel et al. 2017).

\section{Branch out across disciplines and embrace tools and technologies: Providing new opportunities for research} Many citizen science projects are founded in a long tradition of environmental research (e.g., Kullenberg and Kasperowski 2016), and citizen science will gain its full potential from broadening across research arenas to include social sciences and humanities, including health. Emerging information and communication technologies (ICT) have created a wide range of opportunities for interactive participation in scientific research by expanding the scale and scope of data collection, information delivery, the communication of ideas, modes of participant recruiting, communication and data processing, and visualization (Newman et al. 2012). In particular, widespread use of mobile Internet together with increasing use of lowcost sensors provides an opportunity for mass data collection. Games and gamification also are gaining ground as a design approach in citizen science (e.g., Bowser et al. 2013), as they encourage more participants to contribute data for longer periods of time (e.g., Eveleigh et al. 2013) and attract contributors with a range of interests and time availability (e.g., Eveleigh et al. 2014). Furthermore, technological advances make citizen science data more easily available and offer tools for visualizing and analyzing data, allowing citizen scientists to take on active roles beyond collecting data.

As examples, citizen science projects focused on anthropogenic light pollution illustrate the wide range of technologies used for interactive participation (Schroer et al. 2016). These include mobile application-based projects in which users classify sky brightness by reporting how many stars they are able to see in specific constellations with the naked eye (Kyba et al. 2013) or to make decisions on whether individual stars are visible (Loss of the night app). Some projects, such as DarkSkyMeter, use phone cameras as photometers. In addition, web-based projects offer citizen scientists interactive tools to visualize and analyse light measurements (MySkyatNight) and thereby to enhance participation beyond contribution of data. As another example, STARS4ALL is a European collective awareness platform about negative effects of artificial light on human wellbeing, biodiversity, visibility of stars, safety, and energy waste (Schroer et al. 2016, Schroer et al. in press). All of these advances facilitate participation as well as better collection and analyses of data.
A high level of ICT in citizen science, however, does not always guarantee high data quality and participant engagement (Wiggins 2013), especially if resource limitations result in suboptimal ICT with hidden costs due to poor usability or lack of appropriate functionality. Often low-fi technology (e.g., paper and pencil data sheets) may be sufficient for some projects and may allow involvement of younger citizen scientists (Mazumdar et al. in press). A mix of high- and low-tech complementary approaches can thus be advantageous for improving citizen science project outcomes (Venturelli et al. 2016, Wiggins et al. 2013).

Citizen science is also an avenue for opening technologies and promoting open access. Many citizen science applications and projects incorporate open-source software and apps, open hardware, and open-access data and publications. This is a clear sign of maturity in the community: The evolution from one-off applications for use by a specific project toward applications that can be reused by many different activities is a very positive development. Open standards and common vocabularies are key to ensuring interoperability between different applications and their reusability by different communities (Schade and Tsiinaraki 2016). Open access further ensures scientific impact.

\section{Foster active networking and new formats for collaboration: Deepening public participation in the scientific process}

Tools and technologies, however, are not sufficient to ensure successful projects without a strong base of motivated volunteers. To help citizen science reach its fullest potential, projects must welcome a diversity of participants from various backgrounds to ensure innovation at all research stages. This means engaging across the whole spectrum of citizen science formats from contributory to co-created projects, which are jointly designed by citizen scientists with or without academic researchers (Bonney et al. 2009).

Project co-design can increase the social relevance of citizen science by addressing topics of societal interest and enhancing in-depth participation and ownership (Shirk et al. 2012, Ballard et al. in press, Haklay in press). However, co-creation requires skills, time, and identification of specific stakeholders rather than trying to involve the "general public." Citizens often hold important knowledge and can be highly motivated to participate when research is closely aligned with their needs and interests. Involving all relevant groups in citizen science increases the chances of balancing interests and maximizing impact.

Reasons for the current paucity of co-created projects include scientists having an "ivory tower mentality," being insecure in not knowing research questions before a project is started, or simply lacking knowledge, creativity, and confidence for project design. To make co-designed projects more rewarding and feasible for scientists, the overall field of science must widen its key performance indicators, train scientists in principles of public participation, and provide evidence that co-designing projects is worth the effort. Overall, it is important to recognize that participants should be able to choose their level of participation, and that project managers should not presume levels of interests. 
Citizen science is increasingly recognised as part of Open Science, which is one of the three themes of the current EU Research and Innovation policy set out by the European Commission (2016). The main objectives of Open Science are to make science more efficient, transparent, and interdisciplinary and to enable broader societal impact and innovation. In one of the five policy actions leading to a future Open Science Policy Agenda, citizen science is mentioned as a key tool to foster Open Science by opening up the scientific process, promoting best practices, and increasing the input of knowledge. Within this agenda, citizen science is understood to provide participants with multiple roles in the broad spectrum of scientific activities, e.g., as scientist, consumer, decision maker, funder, or observer, benefitting individuals, communities, and researchers. Data quality, ownership, and curation are major issues to be taken into account. One of the broad policy action lines for Open Science is to remove any barriers, e.g., legal, technical, or administrative, whilst protecting individual rights. Embedding Open Science in society through citizen science is a priority to make science more responsive to societal and economic expectations.

\section{Innovation at the Science-Policy Interface}

Many national and international policy developments are aiming for transparency and participation in creating the evidence base and societal acceptance for policy decision making, and these would benefit from a strong link to citizen science. Indeed, examples show that policy takes up scientifically acquired data through different forms of citizen science as a cost-effective and reliable approach to obtaining evidence to underpin policy (Hyder et al. 2015, McKinley et al. 2017). However, the uptake of citizen science data by policy makers is not yet common practice (Hyder et al. 2015). Especially within the context of innovation and policy use, citizen science must pay attention to scientific standards and methods, as well as existing policy or environmental standards, so that results will be used in policy implementation and evaluation. The useful and efficient incorporation of citizen science data and processes into the cycle of policy development requires high-quality data appropriate to the policy decision-making process and a mutual understanding of expectations (Young et al. 2014, Chapman and Hodges 2017).

In this respect, two themes emerge from our recommendations (see Figure 2): The role of citizen science in providing input to existing policy agendas and the opportunities to work with funders.

\section{Embrace opportunities for policy monitoring and development: Facilitating citizen science input for policy implementation}

Citizen science can offer effective ways to connect citizens and policy. Citizens can become involved by playing an active part in creating the evidence base for policy decisions and by understanding and monitoring the changes taking place around them. Such involvement has the potential to significantly impact local and national decision making, empowering citizens, and leading to a better and more transparent government. While citizen science is becoming a valued and useful source of information for governments and the raising of awareness through citizen science is highly appreciated by policy and decision making bodies, the adoption of actual citizen science results in policy development is still slow. Studies in the UK (Davies et al. 2013) and Germany (Brämer 2010) demonstrate vast potential for engagement that remains largely untapped. This may result in part because the specific nature of citizen science data does not always fit policy demands or established indicators or processes (Chapman and Hodges 2017). Interesting successful experiences are occurring at the national, regional, and local levels (Haklay 2015), and these can serve as inspiration for a more integrated approach and more dialogue and knowledge exchange, rather than a one-dimensional communication (Young et al. 2014).

To investigate the potential and limitations of connecting citizen science to environmental policy making, the European Commission and the European Environment Agency endorsed a citizen science Knowledge Innovation Project (KIP) under the Environment Knowledge Community (EKC). KIP is currently exploring how data gathered by citizens can be used to complement environmental monitoring and reporting processes in a cost-effective manner and is reviewing the potential of lay, local, and traditional knowledge to fill knowledge gaps and to examine how the involvement of citizens could foster behavioural changes. The project includes a series of real-life demonstrators in support of environmental legislation in the fields of protected areas and invasive alien species.

Early collaboration of citizen science projects with local authorities can lead to meaningful policy implementation and acceptance by the public. Community-led projects can increase trust in the validity of their methods and results by involving universities and other authoritative organisations alongside local authorities and communities to facilitate successful policy impact. Systematically exploring the challenges associated with building effective partnerships between policy makers and citizen scientists is critical: The process will help to engage citizens and to facilitate empowerment, especially in an era when the bonds of trust between civil society, science, and policymaking need to be strengthened.

Citizen science is already promoted by many European Environmental Protection Agencies (EPAs), as demonstrated by the current Interest Group on Citizen Science of the EPA Network, which exchanges information on initiatives and recommends best practice in citizen science for EPA members. For example, the Scottish Environment Protection Agency (SEPA) offers support for citizen science by providing data handling infrastructure, access to innovative technology, advice on funding models, and access to existing citizen science initiatives and design tools for new projects (Scotland's Environment - Get Involved). Through various partnerships, the agency has produced best practice guidance on appropriate design of citizen science projects relevant to public authorities (Pocock et al. 2014). SEPA supports well-designed citizen science initiatives because they can offer various benefits to regulatory agencies: Assisting policy formulation by providing monitoring 
data, evidence, and intelligence; serving as early warning and screening systems; harnessing volunteer thinking and giving opportunities for public engagement; helping EPA resource efficiency; and operating at useful local, regional, national, and European scales (Owen et al. in press).
Work with science funders: Promoting new and adjusted funding formats

We have previously noted that the European Commission is already supporting different forms of citizen science in its research funding programmes, such as the Collective Awareness Platforms, Citizens' Observatories,

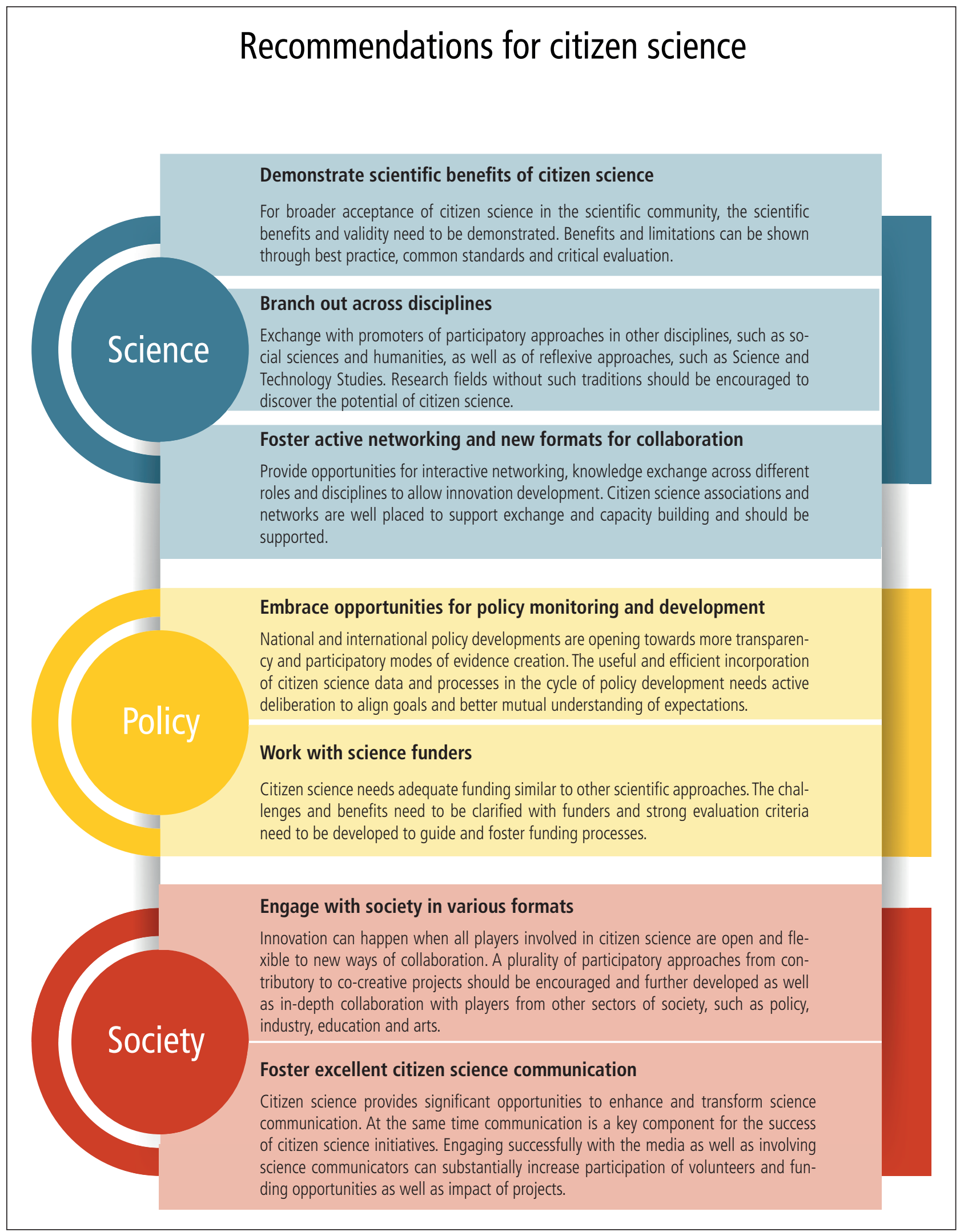

Figure 2: Recommendations for the further development of citizen science. 
and Responsible Research and Innovation projects and activities. In addition, many countries are now developing explicit funding programmes, aided by different citizen science networks. To adjust current funding structures to the demands of citizen science, a joint understanding of citizen science needs and requirements is needed. Often the openness to co-creation and co-designing research questions is implicitly discouraged through traditional funding programmes that demand structured and defined approaches to guarantee specified outcomes (Kieslinger et al. in press). Co-designing research projects may be less attractive to research funders, because goals might be defined only during the research process, and outcomes might be measured by unfamiliar metrics. To unleash the innovative potential of co-created scientific knowledge and societally meaningful outcomes, however, citizen science funding programmes should allow for scoping phases and openness to possible changes in direction or alignments of scientific and societal goals.

\section{Innovation for Society}

The third major innovation avenue links to the innovative potential of citizen science for society. Many citizens are interested in and wish to be more engaged in setting the research agenda as well as participating in actual scientific investigation. Equally, many researchers aim for higher societal relevance of their research and desire the uptake of their research outcomes in solutions for societally important questions. Successful citizen science projects therefore call for inter- and transdisciplinary approaches and adequate formats of interaction.

Here we highlight two main recommendations (Figure 2): Engaging society in various formats, acknowledging innovative approaches to civic involvement, learning, and education; and developing excellence in the role of communication in citizen science.

Engage with society in various formats of citizen science: Fostering innovative approaches to civic involvement, learning, and education, and enhancing the role of museums

Citizen science is seen as an avenue to facilitate more inclusive societies and transformation to sustainability (Buytaert et al. 2014, Hinchliffe et al. 2014) by generating new ideas and innovation to address pressing societal problems. The collaborative arenas that citizen science offers may open up new roles and possibilities for both professional and volunteer partners (Peltola and Arpin in press, Bela et al. 2016, Lawrence 2006). Citizen science also can affect the identities and positions of partners as they develop new sensibilities and framings of problems (Peltola et al. 2017, Hinchliffe et al. 2014, Whatmore 2013, Wilson 2011).

Some citizen science projects have the potential to create new collaborative methods of working and intervening in problems (Landström et al. 2011). These include the ability to reflect the goals of knowledge production or to deal with conflicts of interest. They also can support the exchange of sensible ideas, knowledge sharing, and the formation of new research problems and questions (Hinchliffe et al.
2014). These are examples of the diverse learning outcomes of extended research collectives as coined by Landström et al. (2011). Social learning outcomes and transformations are, however, much harder to document than factual and instrumental learning outcomes, hence they often remain invisible (Bela et al. 2016). According to Bull et al. (2008), the notion of social learning broadens understanding of learning processes. Social learning means that individuals learn to collaborate, reflect on what they are doing, and make collective judgments.

One overarching theme is the role of citizen science in democratising science. No value judgments should be made, however, about the degree of participation in citizen science activities. Arnstein's ladder of participation (Arnstein 1969) assumes that the involvement of citizens in co-creating projects is more significant than in crowdsourcing. However, the model of a ladder is too simplistic to capture the nature of participation in citizen science (Haklay 2013). Examining current knowledge about citizen science participation shows a high level of education for many citizen scientists. Where participants contribute extensively and over a long period of time, skills and credentials blur, with experts both with and without credentials working side by side. Yet meaningful participation also occurs when occasional contributors have a significant encounter with scientific activities, as through a bioblitz. We therefore see consequential participation occurring across the spectrum, in activities that are suitable for the individual, their interests, commitments, responsibilities, and access to technology (see also Lawrence 2006, Arpin in press).

Citizen science initiatives have been categorized based on their degree of openness (Franzoni and Sauermann 2014) and on the type of interaction they allow (Buytaert et al. 2016). Typologies should not be interpreted as normative, however: Not every citizen science project needs to address all kinds of citizen groups to maximize interaction and innovativeness. Involving masses of people-the "crowd" or "data-drones" (Ellis 2014)-requires different tools and approaches than working with groups who need special skills for their tasks. The challenges of engaging a specific interest group (see Peltola et al. 2017) differ in situations where potential participants have high intrinsic motivation and those in which participants are not interested in science or the subject matter per se. Groups with limited skills, level of education, or resources need special attention and means of engaging (Peltola and Arpin in press). The tools used for some projects may exclude groups who feel ill-at-ease using them, thus strengthening existing power relations, marginalizing relevant information, and suppressing ideas. "Full inclusion at the deep level" should therefore not be seen as the only focus for participation in citizen science. Important societal benefits accrue for participation in different types of projects including combinations of high to low skills with high to low engagement in science-a joint activity of creating knowledge that is shared.

In considering partnerships, museums form important gatekeepers between science and society by providing meeting spaces and stepping stones for the active engagement of society in scientific discourse and advancement 
(Sforzi 2017). The majority of natural history museums were founded on the personal collections of amateur collectors, accounting for a long history of amateur and professional collaboration. Today, institutions can play an important role in fostering citizen science activities and expertise, because the dual goals of citizen science-promoting scientific knowledge and education-place museums at an ideal interface with the public in the process of boosting the potential of participatory research. The concept extends from science to the fields of history, archaeology, health, and technology. Over recent years a growing number of museums have developed and promoted innovative citizen science projects, including bioblitzes and other forms of concerted, time-constrained assessment events, ongoing field-based monitoring programmes, and data processing of digitised collections (Ballard et al. 2017). The role of modern museums in citizen science can be embraced even more strongly to move towards inclusion and impact.

\section{Foster excellent citizen science communication: Promoting transformational change}

Professional and high-quality communication is one key factor for project success and for engaging and keeping citizens in the project. Citizen science is attested to contribute to a dramatic change in science communication (Lewenstein 2016) as it takes place in an era of paradigm change (Kuhn 2012) with a move away from a knowledge deficit model to a philosophy of engagement (Schiele 2008). To date, however, the role of science communication in citizen science has only started to be systematically assessed. Citizen science and science communication are both relatively young and highly inter- and transdisciplinary fields of research (Gascoigne et al. 2010, Jordan et al. 2015) that could be more intertwined for mutual exchange and benefit. There is need for changing the reference frame that leads people's understanding from a passive knowledge transfer to active two-way knowledge exchange. Effective communication and collaboration requires an understanding of the motivation of both scientists and citizens who want to make an impact and become actively involved in societally relevant science (Geoghegan et al. 2016, Raddick et al. 2013).

Considering the outreach perspective of science communication, aligning the citizen science research process with the programming schedule of a broadcast station or the print schedule of a popular magazine can be challenging, because science and media work at different speeds and place emphasis on different processes and content. Different needs and communication systems must be clarified to tap into the potential of realizing the role of media as a strong mediator for citizen science without compromising research goals or overstretching available capacities. Moving through the phases of a citizen science project from start to end, early and continuous contact with the media and use of social media can be seen as crucial to raise awareness, facilitate participation, and provide reward and recognition to participants (van Vliet et al. 2014). Talking and interacting with the media enables scientists to reach a large audience and thereby helps to increase public awareness of scientific projects or issues of societal relevance, e.g., the phenology networks in the Netherlands or tick radar and Lyme disease monitoring (van der Kolk et al. 2016, Garcia-Martí et al. 2016). Scaling-up citizen science can be difficult, because scientists must be able to meet the demands of communities in terms of equipment and platform support, but also in terms of communication and interaction. Visualisation and storytelling can be engaging ways to evoke emotions and create identity (Hecker et al. in press), and these skills should be fostered in the citizen science community. We have compiled several recommendations for communication in citizen science projects (Figure $\mathbf{3}$ ).

Citizen science projects should produce high-quality scientific data and findings. These need to be communicated through journal publications and scientific publications. They also need to be communicated with project participants, who have spent their time and resources in producing outcomes. Participants themselves could share experiences of successful participation and project outcomes with their communities and through their own communication channels.

\section{Demonstrating success in citizen science}

To address the pressing issues of global change on the natural world and society, involving broad publics in the process of producing new scientific knowledge is becoming increasingly important. Citizen science offers innovative potential in the fields of science, policy, and society to tackle complex challenges (Hecker et al. in press), and we hope the seven recommendations distilled from the ECSA conference outcomes offer vision and concrete call for action to advance the field.

We now need to demonstrate success in all these arenas. Evaluating outcomes and learning points will improve guidance and recommendations for the field and develop good practice (Kieslinger et al. in press). Importantly, thoughtful evaluation needs to be embedded into a project's design from the start and not as an afterthought. Careful design and definition of desired project outcomes, ongoing monitoring of outcomes and adaptive management, and publishing lessons learned will move the field of citizen science forward.

To document scientific success, peer reviewed and other scholarly publications in different disciplines offer an important indicator, while broad metrics could also include quality-assurance programs, databases, and data visualizations (for a review see also Tredick et al. 2017). Here it will be paramount to allow for different, meaningful formats of citizen participation to add value to research. Success in citizen science also can be manifested in a policy outcome that may lead to a tangible change in people's lives. For example, if evidence from a citizen science project informs urban planning such as a change of bus lines to reduce noise or air pollution in a certain area (Maisonneuve et al. 2009), this is an important policy outcome. To document innovation for society, evaluation of learning outcomes is a growing subfield of citizen science that was launched by 


\section{Recommendations for communication in citizen science}
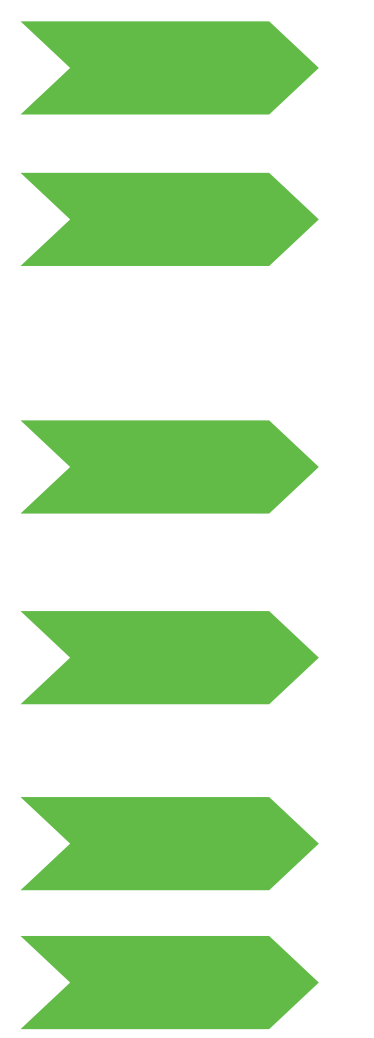

Websites and mobile apps that are easy to use and built with different user groups in mind will attract wider participation.

New technologies such as social media networks and platforms can help project managers to reach more potential participants, support a sense of camaraderie and community amongst participants, provoke more discussion amongst participating volunteers and scientists about the research question, and improve the flow of data outcomes to the participants and the flow of feedback to the organisers (Newman et al. 2010).

Traditional mass media such as newspapers, television, and news presentations have a particularly high audience reach, allowing projects to recruit a large potential audience, motivate participants, and share findings, for example in the Dutch phenology project "Nature's Calendar" (van Vliet et al. 2014) and the German mosquito project "Mueckenatlas" (Walther and Kampen 2017).

A good communication plan is crucial for the success of a citizen science project and needs to be developed at the outset. Communicating with participants throughout the research process and sharing progress and interim outcomes can increase the engagement of participants and the learning of all involved significantly.

Providing for and encouraging participant feedback throughout the project can reveal new opportunities to share informative materials, improve the research and data quality, and increase the educational potential of the project (Druschke and Seltzer 2012).

Face-to-face meetings provide an invaluable opportunity to jointly celebrate success and to show gratitude on behalf of project management and to allow for social interaction and fun as a reward.

Figure 3: Recommendations for communication in citizen science.

the development of numerous scales for measuring varied aspects of learning supported by the US National Science Foundation. This effort included development of a User's Guide for Evaluating Learning Outcomes from Citizen Science (Phillips et al. 2014), and formal and informal educators, including museums, play a major role in this area. In addition, we need to demonstrate how citizen science transforms effective science communication and offers new avenues to engage across society.

Overall, the innovative potential of citizen science should embrace the manifold expertise of participants with different backgrounds across different disciplines, and should incorporate opportunities to work at the science-policy interface and thereby open new perspectives. Citizen science needs to be considered as a suitable approach to face global challenges.

\section{Acknowledgements}

This paper developed out of an international conference organised in May, 2016 by the European Citizen Science Association (ECSA) and the German "Citizens create Knowledge - Knowledge creates Citizens" (GEWISS) programme. We thank all participants for inspiring discussions. Funding for the conference was provided by the German Research Foundation (DFG grant no. BO 1919/21) and more than 24 international partner organisations from science and policy: Helmholtz Centre for Environmental Research (UFZ); German Centre for Integrative Biodiversity Research (iDiv) Halle-Jena-Leipzig; FriedrichSchiller-Universität Jena; Museum für Naturkunde, Berlin; Berlin-Brandenburg Institute of Advanced Biodiversity Research; Wissenschaft im Dialog; Center for Ecology \& Hydrology; Muséum National d'Histoire Naturelle Paris; Museum for Natural History London; Museo di Storia Naturale della Marremma; Fondazione Grosseta Cultura; University College London (UCL); Austrian Federal Ministry of Education, Science and Research (BMBWF); Leibniz-Institute of Freshwater Ecology and Inland Fisheries (IGB); Leibniz-Institute for Zoo and Wildlife (IZW); Leibniz Centre for Agricultural Landscape Research (ZALF); EarthWatch Institute; Zoological Research Museum Alexander Koenig; Haus der Zukunft/Futurium Berlin; HelmholtzGemeinschaft; Irstea; British Ecological Society; Science Hack Day Berlin. The ThinkCamp was sponsored by Writelatex Limited.

Without their support, this conference would not have been possible, nor would the development of citizen science in Europe be taking speed as it currently is. We also thank two anonymous reviewers for their constructive and encouraging comments that helped to improve the paper and the editorial team of CSTP for its professional handling of the publication process. 


\section{Competing Interests}

One of the authors of this paper, Rick Bonney, is editor-inchief of this journal. He had no involvement in the review process other than addressing reviewer questions.

\section{References}

Arnstein, S.R. 1969. Ladder of citizen participation. Journal of the American Institute of Planners, 35(4): 216-224. DOI: https://doi.org/10.1080/01944366908977225

Ashcroft, R. 2016. They walk among us: The rise of citizen science. Environmental Scientist, 25(2), Special Issue.

Atlas of Living Australia. Available at: www.ala.org.au [Last accessed 10 November 2017].

Australian Citizen Science Association - ACSA. Available at: https://www.citizenscience.org.au/ [Last accessed 10 November 2017].

Ballard, H.L., Robinson, L.D., Young, A.N., Pauly, G.B., Higgins, L.M., Johnson, R.F. and Tweddle, J.C. 2017. Contributions to conservation outcomes by natural history museum-led citizen science: Examining evidence and next steps. Biological Conservation, 208: 87-97. DOI: https://doi.org/10.1016/j.biocon.2016.08.040

Bela, G., Peltola, T., Young, J.C., Balazs, B., Arpin, I., Pataki, G., Hauck, J., Kelemen, E., Kopperoinen, L., Van Herzele, A., Keune, H., Hecker, S., Suskevics, M., Roy, H.E., Itkonen, P., Kulvik, M., Laszlo, M., Basnou, C., Pino, J. and Bonn, A. 2016. Learning and the transformative potential of citizen science. Conservation Biology, 30(5): 990-999. DOI: https://doi.org/10.1111/cobi.12762

Bonn, A., Richter, A., Vohland, K., Pettibone, L., Brandt, M., Feldmann, R., Goebel, C., Grefe, C., Hecker, S., Hennen, L., Hofer, H., Kiefer, S., Klotz, S., Kluttig, T., Krause, J., Küsel, K., Liedtke, C., Mahla, A., Neumeier, V., PremkeKraus, M., Rillig, M.C., Röller, O., Schäffler, L., Schmalzbauer, B., Schneidewind, U., Schumann, A., Settele, J., Tochtermann, K., Tockner, K., Vogel, J., Volkmann, W., von Unger, H., Walther, D., Weisskopf, M., Wirth, C., Witt, T., Wolst, D. and Ziegler, D. 2016. Greenpaper Citizen Science Strategy 2020 for Germany. Available at: http://www.buergerschaffenwissen.de/citizen-science/ ressourcen [Last accessed 10 November 2017].

Bonney, R., Ballard, H., Jordan, R., McCallie, E., Phillips, T., Shirk, J. and Wilderman, C.C. 2009. Public Participation in Scientific Research: Defining the Field and Assessing Its Potential for Informal Science Education. A CAISE Inquiry Group Report. Washington, D.C.: Center for Advancement of Informal Science Education (CAISE).

Bonney, R., Cooper, C.B., Dickinson, J., Kelling, S., Phillips, T., Rosenberg, K.V. and Shirk, J. 2009. Citizen Science: A Developing Tool for Expanding Science Knowledge and Scientific Literacy. Bioscience, 59(11): 977-984. DOI: https://doi.org/10.1525/bio.2009.59.11.9

Bonney, R., Phillips, T.B., Ballard, H.L. and Enck, J.W. 2016. Can citizen science enhance public understanding of science? Public Understanding of Science, 25(1): 2-16. DOI: https://doi.org/10.1177/0963662515607406

Bonney, R., Shirk, J.L., Phillips, T.B., Wiggins, A., Ballard, H.L., Miller-Rushing, A.J. and Parrish, J.K. 2014. Next steps for citizen science. Science, 343(6178): 1436-1437. DOI: https://doi.org/10.1126/science.1251554
Bowser, A., Hansen, D. and Preece, J. 2013. Gamifying citizen science: Lessons and future directions. $\mathrm{CHI}$ '13 Extended Abstracts on Human Factors in Computing Systems, Paris, 27 April-02 May 2013, 3263-3266.

Brämer, R. 2010 Natur: Vergessen?: Erste Befunde des Jugendreports Natur 2010. Information. Medien. Agrar $\mathrm{eV}$.

Brossard, D., Lewenstein, B. and Bonney, R. 2005. Scientific knowledge and attitude change: The impact of a citizen science project. International Journal of Science Education, 27(9): 1099-1121. DOI: https://doi. org/10.1080/09500690500069483

Bull, R., Petts, J. and Evans, J. 2008. Social learning from public engagement: dreaming the impossible? Journal of environmental planning and management, 51(5): 701-716. DOI: https://doi. org/10.1080/09640560802208140

Bürger schaffen Wissen. Available at: www.buergerschaffenwissen.de [Last accessed 10 November 2017].

Buytaert, W., Dewulf, A., De Bievre, B., Clark, J. and Hannah, D.M. 2016. Citizen Science for Water Resources Management: Toward Polycentric Monitoring and Governance? Journal of Water Resources Planning and Management, 142(4): 4. DOI: https://doi.org/10.1061/ (ASCE)WR.1943-5452.0000641

Buytaert, W., Zulkafli, Z., Grainger, S., Acosta, L., Alemie, T.C., Bastiaensen, J., De Bièvre, B., Bhusal, J., Clark, J., Dewulf, A., Foggin, M., Hannah, D.M., Hergarten, C., Isaeva, A., Karpouzoglou, T., Pandeya, B., Paudel, D., Sharma, K., Steenhuis, T., Tilahun, S., Van Hecken, G. and Zhumanova, M. 2014. Citizen science in hydrology and water resources: opportunities for knowledge generation, ecosystem service management, and sustainable development. Frontiers in Earth Science, 2: 26. DOI: https://doi.org/10.3389/feart.2014.00026

Chapman, C. and Hodges, C. 2017. Can Citizen Science Seriously Contribute to Policy Development?: A Decision Maker's View. In: Luigi, C. and Jaume, P. (eds.), Analyzing the Role of Citizen Science in Modern Research, 246-261. Hershey, PA, USA: IGI Global. DOI: https://doi.org/10.4018/978-1-52250962-2.ch012.

Citizen Science Association - CSA. Available at: http:// citizenscience.org [Last accessed 10 November 2017].

CitSci.org. Available at: www.citsci.org [Last accessed 10 November 2017].

CitizenScience.gov. Available at: www.citizenscience.gov [Last accessed 10 November 2017].

Cronje, R., Rohlinger, S., Crall, A. and Newman, G. 2011. Does Participation in Citizen Science Improve Scientific Literacy? A Study to Compare Assessment Methods. Applied Environmental Education and Communication, 10(3): 135-145. DOI: https://doi.org/10.1111/j.1755263X.2011.00196.X

Davies, L., Gosling, L., Bachariou, C., Eastwood, J., Fradera, R., Manomaiudom, N. and Robins, S. 2013. OPAL Community Environment Report - Exploring Nature Together, London. Available at: https://www.opalexplorenature.org/ENTreport [Last accessed 10 November 2017]. 
Dickinson, J.L., Shirk, J., Bonter, D., Bonney, R., Crain, R.L., Martin, J., Phillips, T. and Purcell, K. 2012. The current state of citizen science as a tool for ecological research and public engagement. Frontiers in Ecology and the Environment, 10(6): 291-297.

Dickinson, J.L., Zuckerberg, B. and Bonter, D.N. 2010. Citizen Science as an Ecological Research Tool: Challenges and Benefits. In: Futuyma, D.J., Shafer, H.B. and Simberloff, D. (eds.), Annual Review of Ecology, Evolution, and Systematics, 41: 149-172. DOI: https://doi. org/10.1146/annurev-ecolsys-102209-144636

Druschke, C.G. and Seltzer, C.E. 2012. Failures of Engagement: Lessons Learned from a Citizen Science Pilot Study. Applied Environmental Education \& Communication, 11(3-4): 178-188. DOI: https://doi.org/10.10 80/1533015X.2012.777224

ECSA conference 2016. Available at: www.ecsa2016.eu [Last accessed 10 November 2017].

Eitzel, M.V., Cappadonna, J.L., Santos-Lang, C., Duerr, R.E., Virapongse, A., West, S.E., Kyba, C.C.M., Bowser, A., Cooper, C.B., Sforzi, A., Metcalfe, A.N., Harris, E.S., Thiel, M., Haklay, M., Ponciano, L., Roche, J., Ceccaroni, L., Shilling, F.M., Dörler, D., Heigl, F., Kiessling, T., Davis, B.Y. and Jiang, Q. 2017. Citizen Science Terminology Matters: Exploring Key Terms. Citizen Science: Theory and Practice, 2(1): 1. DOI: https://doi.org/10.5334/cstp.96

Ellis, S. 2014. A history of collaboration, a future in crowdsourcing: Positive impacts of cooperation on British librarianship. Libri, 64(1): 1-10. DOI: https://doi. org/10.1145/1924475.1924481

Ellwood, E.R., Crimmins, T.M. and Miller-Rushing, A.J. 2017. Citizen science and conservation: Recommendations for a rapidly moving field. Biological Conservation, 208: 1-4. DOI: https://doi.org/10.1016/j.biocon.2016.10.014

European Citizen Science Association - ECSA. Available at: http://ecsa.citizen-science.net [Last accessed 10 November 2017].

European Commissio. 2016. Open innovation, open science, open to the world - a vision for Europe Belgium: Brussels. Available at: https://ec.europa.eu/digital-single-market/en/news/open-innovation-open-scienceopen-world-vision-europe [Last accessed 10 November 2017].

Eveleigh, A., Jennett, C., Blandford, A., Brohan, P. and Cox, A.L. 2014. Designing for dabblers and deterring drop-outs in citizen science. Proceedings of the 32nd annual ACM conference on Human factors in computing systems, Toronto, Ontario, Canada, 26 April - 01 May 2014, 2985-2994. DOI: https://doi. org/10.1145/2556288.2557262

Eveleigh, A., Jennett, C., Lynn, S. and Cox, A.L. 2013. "I want to be a captain! i want to be a captain!": Gamification in the old weather citizen science project. Proceedings of the first international conference on gameful design, research, and applications, Toronto, Ontario, Canada, 02-04 October 2013, 79-82.

Fowler, A., Whyatt, J.D., Davies, G. and Ellis, R. 2013. How reliable are citizen-derived scientific data? Assessing the quality of contrail observations made by the gen- eral public. Transactions in GIS, 17(4): 488-506. DOI: https://doi.org/10.1111/tgis.12034

Franzoni, C. and Sauermann, H. 2014. Crowd science: The organization of scientific research in open collaborative projects. Research Policy, 43(1): 1-20. DOI: https://doi.org/10.1016/j.respol.2013.07.005

Fritz, S. and Fonte, C.C. 2016. Citizen Science and Earth Observation. Remote Sensing, Special Issue.

Garcia-Martí, I., Zurita-Milla, R., Swart, A., van den Wijngaard, K.C., van Vliet, A.J., Bennema, S. and Harms, M. 2016. Identifying environmental and human factors associated with tick bites using volunteered reports and frequent pattern mining. Transactions in GIS, 21(2): 277-299. DOI: https://doi.org/10.1111/tgis.12211

Gascoigne, T., Cheng, D., Claessens, M., Metcalfe, J., Schiele, B. and Shi, S. 2010. Is science communication its own field? Journal of science communication, 9(3): 1-6.

Geoghegan, H., Dyke, A., Pateman, R., West, S. and Everett, G. 2016. Understanding motivations for citizen science. Available at: http://www.ukeof.org.uk/resources/ citizen-science-resources/MotivationsforCSREPORTFINALMay2016.pdf [Last accessed 10 November 2017].

Göbel, C., Cappadonna, J.L., Newman, G.J., Jian Zhang, E. and Vohland, K. 2016. More Than Just Networking for Citizen Science: Examining Core Roles of Practitioner Organizations. In: Ceccaroni, L. and Piera, J. (eds.), Analyzing the Role of Citizen Science in Modern Research, 24-48. Hershey, PA, USA.

Gold, M. 2016. Storify. Available at: https://storify.com/ MobileMaggie/ecsa-2016-berlin [Last accessed 10 November 2017].

Gold, M. and Ochu, E. In press. Creative collaboration in citizen science and the evolution of ThinkCamps. In: Hecker, S., et al. (eds.), Citizen Science - Innovation in Open Science, Society and Policy. London: UCL Press.

Haklay, M. 2013. Citizen Science and Volunteered Geographic Information - overview and typology of participation. In: Sui, D.Z., Elwood, S. and Goodchild, M.F. (eds.), Crowdsourcing Geographic Knowledge: Volunteered Geographic Information (VGI) in The ory and Practice. Berlin: Springer. DOI: https://doi. org/10.1007/978-94-007-4587-2_7

Haklay, M. 2015. Citizen science and policy: a European perspective. The Wodrow Wilson Center, Commons Lab.

Haklay, M. 2016. Po Ve Sham. Available at: https://povesham.wordpress.com/ [Last accessed 10 November 2017].

Hecker, S., Haklay, M., Bowser, A., Makuch, Z., Vogel, J. and Bonn, A. (eds.). In press. Citizen Science - Innovation in Open Science, Society and Policy. London: UCL Press.

Hecker, S., Luckas, M., Brandt, M., Kikillus, H., Leonhard, C., Marenbach, I., Schiele, B., Sieber, A., Vliet, A.J.H.v., Walz, $\mathrm{U}$. and Wende, W. Stories can change the world - The innovative potential of citizen science communication. In: Hecker, S., et al. (eds.), Citizen Science - Innovation in Open Science, Society and Policy (in press). London: UCL Press.

Henderson, S. 2012. Citizen science comes of age. Frontiers in Ecology and the Environment, 10(6): 283-283. DOI: https://doi.org/10.1890/1540-9295-10.6.283 
Hinchliffe, S., Levidow, L. and Oreszczyn, S. 2014. Engaging cooperative research. Environment and Planning A, 46(9): 2080-2094. DOI: https://doi.org/10.1068/ a140061p

Hochachka, W.M., Fink, D., Hutchinson, R.A., Sheldon, D., Wong, W.-K. and Kelling, S. 2012. Data-intensive science applied to broad-scale citizen science. Trends in Ecology \& Evolution, 27(2): 130-137. DOI: https://doi. org/10.1016/j.tree.2011.11.006

Hyder, K., Townhill, B., Anderson, L.G., Delany, J. and Pinnegar, J.K. 2015. Can citizen science contribute to the evidence-base that underpins marine policy? Marine policy, 59: 112-120. DOI: https://doi. org/10.1016/j.marpol.2015.04.022

Jordan, R.C., Crall, A., Gray, S., Phillips, T. and Mellor, D. 2015. Citizen Science as a Distinct Field of Inquiry. Bioscience, 65(2): 208-211. DOI: https://doi.org/10.1093/ biosci/biu 217

Jordan, R.C., Gray, S.A., Howe, D.V., Brooks, W.R. and Ehrenfeld, J.G. 2011. Knowledge Gain and Behavioral Change in Citizen-Science Programs. Conservation Biology, 25(6): 1148-1154. DOI: https://doi. org/10.1111/j.1523-1739.2011.01745.x

Kamp, J., Oppel, S., Heldbjerg, H., Nyegaard, T. and Donald, P.F. 2016. Unstructured citizen science data fail to detect long-term population declines of common birds in Denmark. Diversity and Distributions, 22(10): 1024-1035. DOI: https://doi.org/10.1111/ddi.12463

Kasperowski, D. and Kullenberg, C. In press. Citizen Science. Science \& Technology Studies, Special Issue.

Kieslinger, B., Schäfer, T., Heigl, F., Dörler, D., Richter, A. and Bonn, A. In press. Evaluating Citizen Science: Towards an open framework. In: Hecker, S., et al. (eds.), Citizen Science - Innovation in Open Science, Society and Policy. London: UCL Press.

Kosmala, M., Wiggins, A., Swanson, A. and Simmons, B. 2016. Assessing data quality in citizen science. Frontiers in Ecology and the Environment, 14(10): 551-560. DOI: https://doi.org/10.1002/fee.1436

Kuhn, T. 2012 (1962). The Structure of Scientific Revolutions, Chicago: University of Chicago Press. DOI: https://doi. org/10.7208/chicago/9780226458144.001.0001

Kullenberg, C. and Kasperowski, D. 2016. What Is Citizen Science? - A Scientometric Meta-Analysis. PLOS ONE, 11(1): e0147152. DOI: https://doi.org/10.1371/journal.pone.0147152

Kyba, C.C.M., Wagner, J.M., Kuechly, H.U., Walker, C.E., Elvidge, C.D., Falchi, F., Ruhtz, T., Fischer, J. and Hölker, F. 2013. Citizen Science Provides Valuable Data for Monitoring Global Night Sky Luminance. Scientific Reports, 3. DOI: https://doi.org/10.1038/srep01835

Landström, C., Whatmore, S.J., Lane, S.N., Odoni, N.A., Ward, N. and Bradley, S. 2011. Coproducing flood risk knowledge: redistributing expertise in critical 'participatory modelling'. Environment and Planning A, 43(7): 1617-1633. DOI: https://doi.org/10.1068/a43482

Lawrence, A. 2006. 'No personal motive? 'Volunteers, biodiversity, and the false dichotomies of participation. Ethics Place and Environment, 9(3): 279-298. DOI: https://doi.org/10.1080/13668790600893319
Lewenstein, B.V. 2016. Can we understand citizen science? Jcom-Journal of Science Communication, 15(1): 5.

Loss of the night app. Available at: http://lossofthenight. blogspot.de [Last accessed 10 November 2017].

Lukyanenko, R., Parsons, J. and Wiersma, Y.F. 2016. Emerging problems of data quality in citizen science. Conservation Biology, 30(3): 447-449. DOI: https://doi. org/10.1111/cobi.12706

Maisonneuve, N., Stevens, M., Niessen, M.E. and Steels, L. 2009. NoiseTube: Measuring and mapping noise pollution with mobile phones. In: Athanasiadis, I.N., Mitkas, P.A., Rizzoli, A.E. and Gomez, J.M. (eds.), Information Technologies in Environmental Engineering, 215-228. DOI: https://doi. org/10.1007/978-3-540-88351-7_16

Mazumdar, S., Ceccaroni, L., Piera, J., Hölker, F., Berre, A.J., Arlinghaus, R. and Bowser, A. In press. Diversity of Citizen Science Technologies: Traditional and New Opportunities for Interactive Participation in Scientific Research. In: Hecker, S., et al. (eds.), Citizen Science Innovation in Open Science, Society and Policy. London: UCL Press.

McKinley, D.C., Miller-Rushing, A.J., Ballard, H.L., Bonney, R., Brown, H., Cook-Patton, S.C., Evans, D.M., French, R.A., Parrish, J.K., Phillips, T.B., Ryan, S.F., Shanley, L.A., Shirk, J.L., Stepenuck, K.F., Weltzin, J.F., Wiggins, A., Boyle, O.D., Briggs, R.D., Chapin III, S.F., Hewitt, D.A., Preuss, P.W. and Soukup, M.A. 2017. Citizen science can improve conservation science, natural resource management, and environmental protection. Biological Conservation, 208: 15-28. DOI: https://doi. org/10.1016/j.biocon.2016.05.015

Merenlender, A.M., Crall, A.W., Drill, S., Prysby, M. and Ballard, H. 2016. Evaluating environmental education, citizen science, and stewardship through naturalist programs. Conservation Biology, 30(6): 1255-1265. DOI: https://doi.org/10.1111/cobi.12737

MySkyatNight. Available at: http://www.myskyatnight. com [Last accessed 10 November 2017].

Newman, G., Wiggins, A., Crall, A., Graham, E., Newman, S. and Crowston, K. 2012. The future of citizen science: emerging technologies and shifting paradigms. Frontiers in Ecology and the Environment, 10(6): 298-304. DOI: https://doi.org/10.1890/110294

Newman, G., Zimmerman, D., Crall, A., Laituri, M., Graham, J. and Stapel, L. 2010. User-friendly web mapping: lessons from a citizen science website. International Journal of Geographical Information Science, 24(12): 1851-1869. DOI: https://doi.org/10.1080/13658816 .2010 .490532

Österreich forscht. Available at: www.citizen-science.at [Last accessed 10 November 2017].

Owen, R. and Parker, A.J. In press. Citizen Science and Environmental Protection. In: Hecker, S., et al. (eds.), Citizen Science - Innovation in Open Science, Society and Policy. London: UCL Press.

Peltola, T., Åkerman, M., Bamberg, J., Lehtonen, P. and Ratamäki, O. 2017. Emergent publics and affects in environmental governance. Journal of Environmental Policy and Planning. DOI: https://doi.org/10.1080/15 23908X.2017.1343135 
Peltola, T. and Arpin, I. In press. Science for everybody? Bridging the socio-economic gap in urban biodiversity monitoring. In: Hecker, S., et al. (eds.), Citizen Science Innovation in Open Science, Society and Policy. London: UCL Press.

Pettibone, L., Vohland, K., Bonn, A., Richter, A., Bauhus, W., Behrisch, B., Borcherding, R., Brandt, M., Bry, F., Dörler, D., Elbertse, I., Glöckler, F., Göbel, C., Hecker, S., Heigl, F., Herdick, M., Kiefer, S., Kluttig, T., Kühn, E., Kühn, K., Oswald, K., Röller, O., Schefels, C., Schierenberg, A., Scholz, W., Schumann, A., Sieber, A., Smolarski, R., Tochtermann, K., Wende, W. and Ziegler, D. 2016. Citizen science for all - A guide for citizen science practitioners. Available at: http://www.buergerschaffenwissen.de/citizen-science/ ressourcen [Last accessed 10 November 2017].

Pettorelli, N. 2017. New Approaches to Citizen Science. Remote Sensing in Ecology and Conservation [Special issue in press.], Special Issue.

Phillips, T.B. 2017. Engagement and learning in environmentally-based citizen science: A mixed-methods comparative case study. (Ph.D. Thesis). Cornell University, Ithaca, NY.

Phillips, T.B., Ferguson, M., Minarchek, M., Porticella, N. and Bonney, R. 2014. User's Guide for Evaluating Learning Outcomes in Citizen Science. Ithaca, NY. Available at: http://www.birds.cornell.edu/citscitoolkit/evaluation [Last accessed 10 November 2017].

Pocock, M.J.O., Chapman, D.S., Sheppard, L.J. and Roy, H.E. 2014. Choosing and using citizen science: a guide to when and how to use citizen science to monitor biodiversity and the environment. NERC/Centre for Ecology \& Hydrology.

Raddick, M., Bracey, G., Gay, P.L., Lintott, C.J., Cardamone, C., Murray, P., Schawinski, K., Szalay, A.S. and Vandenberg, J. 2013. Galaxy zoo: Motivations of citizen scientists. Astronomy Education Review, 12(1): 1-41.

Ramanauskaite, E.M. and Haklay, M. 2017. Creativity and Learning in Citizen Cyberscience - Lessons from the Citizen Cyberlab Summit. Human Computation, 3(1): 5-24. Special Issue on Learning and Creativity in Citizen Science. DOI: https://doi.org/10.15346/hc.v3i1.3

Richter, A., Dörler, D., Hecker, S., Heigl, F., Pettibone, L., Sanz, F.S., Vohland, K. and Bonn, A. In press. Benefits from capacity building in citizen science: insights from strategic development programs in Europe. In: Hecker, S., et al. (eds.), Citizen Science - Innovation in Open Science, Society and Policy. London: UCL Press.

Riesch, H. and Potter, C. 2014. Citizen science as seen by scientists: Methodological, epistemological and ethical dimensions. Public Understanding of Science, 23(1): 107-120. DOI: https://doi.org/10.1177/0963662513497324

Riesch, H., Potter, C. and Davies, L. 2013. Combining citizen science and public engagement: The open airlaboratories programme. Journal of Science Communication, 12(3).

Robinson, L.D., Cawthray-Syms, J.L., West, S.E., Bonn, A. and Ansine, J. In press. Ten Principles of Citizen Science. In: Hecker, S., et al. (eds.), Citizen Science - Innovation in Open Science, Society and Policy. London: UCL Press.

Schade, S. and Tsiinaraki, C. 2016. Survey Report: Data Management in Citizen Science Projects. Publica- tion Office of the European Union: Luxembourg. DOI: https://doi.org/10.2788/539115

Schiele, B. 2008. On and about the deficit model in an age of free flow. In: Cheng, D., Claessens, M., Gascoigne, T., Metcalfe, J., et al. (eds.), Communicating science in social contexts - New models, new practices, 91-117. Springer. DOI: https://doi.org/10.1007/978-1-4020-8598-7_6

Schroer, S., Corcho, O. and Hölker, F. 2016. The impact of citizen science on research about artificial light at night. Environmental Scientist, 25(2): 18-24.

Schroer, S., Kyba, C.C.M., van Grunsven, R., Celino, I., Corcho, O. and Hölker, F. In press. Citizen science efforts in environmental monitoring of light pollution. In: Hecker, S., et al. (eds.), Citizen Science - Innovation in Open Science, Society and Policy. London: UCL Press.

Schweiz forscht. Available at: www.schweiz-froscht.ch [Last accessed 10 November 2017].

SciStarter. Available at: scistarter.com [Last accessed 10 November 2017].

Scotland's Environment - Get Involved. Available at: http://www.environment.scotland.gov.uk/get-involved [Last accessed 10 November 2017].

Scottish Citizen Science Portal. Available at: https://envscot-csportal.org.uk/ [Last accessed 10 November 2017].

Serrano Sanz, F., Holocher-Ertl, T., Kieslinger, B., Sanz García, F. \& Silva, C.G. 2014. White paper on citizen science for Europe. S. c. Available at: http://www.socientize. eu/?q=eu/content/download-socientize-white-paper [Last accessed 10 November 2017].

Sforzi, A. 2017. Citizen Science as a tool for enhancing the role of a museum. Museologia Scientifica Memorie, 16: 124-128.

Shirk, J., Ballard, H.L., Wilderman, C.C., Phillips, T., Wiggins, A., Jordan, R., McCallie, E., Minarchek, M., Lewenstein, B.V., Krasny, M.E. and Bonney, R. 2012. Public Participation in Scientific Research: a Framework for Deliberate Design. Ecology and Society, 17(2): 29. DOI: https:// doi.org/10.5751/ES-04705-170229

Shirk, J. and Bonney, R. In press. Scientific impacts and innovations of citizen science. In: Hecker, S., et al. (eds.), Citizen Science - Innovation in Open Science, Society and Policy. London: UCL Press.

Storksdieck, M., Shirk, J.L., Cappadonna, J.L., Domroese, M., Göbel, C., Haklay, M., Miller-Rushing, A.J., Roetman, P., Sbrocchi, C. and Vohland, K. 2016. Associations for Citizen Science: Regional Knowledge, Global Collaboration. Citizen Science: Theory and Practice, 1(2): 10. DOI: https://doi.org/10.5334/cstp.55

Sullivan, B.L., Aycrigg, J.L., Barry, J.H., Bonney, R.E., Bruns, N., Cooper, C.B., Damoulas, T., Dhondt, A.A., Dietterich, T., Farnsworth, A., Fink, D., Fitzpatrick, J.W., Fredericks, T., Gerbracht, J., Gomes, C., Hochachka, W.M., Iliff, M.J., Lagoze, C., La Sorte, F.A., Merrifield, M., Morris, W., Phillips, T.B., Reynolds, M., Rodewald, A.D., Rosenberg, K.V., Trautmann, N.M., Wiggins, A., Winkler, D.W., Wong, W.-K., Wood, C.L., Yu, J. and Kelling, S. 2014. The eBird enterprise: An integrated approach to development and application of citizen science. Biological Conservation, 169: 31-40. DOI: https://doi.org/10.1016/j.biocon.2013.11.003 
Sullivan, B.L., Phillips, T., Dayer, A.A., Wood, C.L., Farnsworth, A., Iliff, M.J., Davies, I.J., Wiggins, A., Fink, D., Hochachka, W.M., Rodewald, A.D., Rosenberg, K.V., Bonney, R. and Kelling, S. 2017. Using open access observational data for conservation action: A case study for birds. Biological Conservation, 208: 5-14. DOI: https://doi.org/10.1016/j.biocon.2016.04.031

Tancoigne, E. 2017. Four things Twitter tells us about "Citizen Science" (and 1,000 things it doesn't). Available at: http://citizensciences.net/2017/01/26/4-thingstwitter-tells-us-about-citizen-science/ [Last accessed 10 November 2017].

Tredick, C.A., Lewison, R.L., Deutschman, D.H., Hunt, T.A., Gordon, K.L. and Von Hendy, P. 2017. A Rubric to Evaluate Citizen-Science Programs for Long-Term Ecological Monitoring. BioScience, 67(9): 834-844. DOI: https:// doi.org/10.1093/biosci/bix090

Trumbull, D.J., Bonney, R., Bascom, D. and Cabral, A. 2000. Thinking scientifically during participation in a citizen-science project. Science Education, 84(2): 265-275. DOI: https://doi.org/10.1002/(SICI)1098237X(200003)84:2<265::AID-SCE7>3.0.CO;2-5

Tulloch, A.I.T., Possingham, H.P., Joseph, L.N., Szabo, J. and Martin, T.G. 2013. Realising the full potential of citizen science monitoring programs. Biological Conservation, 165: 128-138. DOI: https://doi.org/10.1016/j.biocon.2013.05.025

van der Kolk, H.-J., WallisDeVries, M.F. and Van Vliet, A.J. 2016. Using a phenological network to assess weather influences on first appearance of butterflies in the Netherlands. Ecological Indicators, 69: 205-212. DOI: https://doi.org/10.1016/j.ecolind.2016.04.028

van Vliet, A.J.H., Bron, W.A. and Mulder, S. 2014. The how and why of societal publications for citizen science projects and scientists. International Journal of Biometeorology, 58(4): 565-577. DOI: https://doi.org/10.1007/ s00484-014-0821-9

Vann-Sander, S., Clifton, J. and Harvey, E. 2016. Can citizen science work? Perceptions of the role and utility of citizen science in a marine policy and management context. Marine Policy, 72: 82-93. DOI: https://doi. org/10.1016/j.marpol.2016.06.026

Vantieghem, P., Maes, D., Kaiser, A. and Merckx, T. 2016. Quality of citizen science data and its consequences for the conservation of skipper butterflies (Hesperiidae) in Flanders (northern Belgium). Journal of Insect Conservation, 1-13. DOI: https://doi.org/10.1007/s10841016-9924-4

Venturelli, P.A., Hyder, K. and Skov, C. 2016. Angler apps as a source of recreational fisheries data: opportunities, challenges and proposed standards. Fish and Fisheries. DOI: https://doi.org/10.1111/faf.12189

Walther, D. and Kampen, H. 2017. The Citizen Science Project 'Mueckenatlas' Helps Monitor the Distribution and Spread of Invasive Mosquito Species in Germany. Journal of Medical Entomology, 54(6): 1790-1794. DOI: https://doi.org/10.1093/jme/tjx166

Weitkamp, E. 2016. Telling stories about our research. Journal of Science Communication, 15(2).

Whatmore, S. 2013. Earthly Powers and Affective Environments: An Ontological Politics of Flood Risk. Theory, Culture \& Society, 30(7/8): 33-50. DOI: https://doi. org/10.1177/0263276413480949

Wiggins, A. 2013. Free as in puppies: compensating for ICT constraints in citizen science. Proceedings of the 2013 conference on Computer supported cooperative work, 1469-1480. DOI: https://doi.org/10.1145/ 2441776.2441942

Wiggins, A., Bonney, R., Graham, E., Henderson, S., Kelling, S., LeBuhn, G., Litauer, R., Lots, K., Michener, W. and Newman, G. 2013. Data management guide for public participation in scientific research. DataOne Working Group, 1-41.

Wilson, M. 2011. Data matter(s): Legitimacy, coding, and qualifications-of-life. Environment and Planning D: Society and Space, 29: 857-872. DOI: https://doi. org/10.1068/d7910

Young, J.C., Waylen, K.A., Sarkki, S., Albon, S., Bainbridge, I., Balian, E., Davidson, J., Edwards, D., Fairley, R., Margerison, C., McCracken, D., Owen, R., Quine, C.P., Stewart-Roper, C., Thompson, D., Tinch, R., Van den Hove, S. and Watt, A. 2014. Improving the sciencepolicy dialogue to meet the challenges of biodiversity conservation: having conversations rather than talking at one-another. Biodiversity and Conservation, 23(2): 387-404. DOI: https://doi.org/10.1007/s10531-0130607-0

Zooniverse. Available at: https://www.zooniverse.org/ [Last accessed 10 November 2017].

\footnotetext{
How to cite this article: Hecker, S., Bonney, R., Haklay, M., Hölker, F., Hofer, H., Goebel, C., Gold, M., Makuch, Z., Ponti, M., Richter, A., Robinson, L., Iglesias, J.R., Owen, R., Peltola, T., Sforzi, A., Shirk, J., Vogel, J., Vohland, K., Witt, T. and Bonn, A. 2018 Innovation in Citizen Science - Perspectives on Science-Policy Advances. Citizen Science: Theory and Practice, 3(1): 4, pp. 1-14, DOI: https://doi. org/10.5334/cstp.114

Submitted: 20 June 2017 Accepted: 29 March 2018 Published: 27 April 2018
}

Copyright: ( 2018 The Author(s). This is an open-access article distributed under the terms of the Creative Commons Attribution 4.0 International License (CC-BY 4.0), which permits unrestricted use, distribution, and reproduction in any medium, provided the original author and source are credited. See http://creativecommons.org/licenses/by/4.0/.

] $\mathrm{u}[\quad$ Citizen Science: Theory and Practice is a peer-reviewed open access journal published by Ubiquity Press. 